The Israeli Journal of Aquaculture IJA.73.2021.1526990, 16 pages

CCBY-NC-ND-4.0 • https://doi .org/10.46989/001c.29495

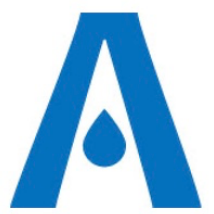

The $I J A$ is a peer-reviewed open-access, electronic journal, freely available without charge to users

Produced by the AquacultureHub non-profit Foundation Sale of $I J A$ papers is strictly forbidden

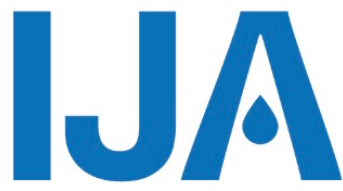

\title{
Structure, proximate composition, nutrient dynamics and growth characteristics of Penaeus vannamei in indoor biofloc systems with three different salinities and carbon sources
}

\author{
Theivasigamani Anand ${ }^{1 *}$, Arasan Srinivasan ${ }^{2}$, Pandurengan \\ Padmavathy $^{3}$, Paulraj Jawahar ${ }^{2}$, J. Stephen Sampathkumar ${ }^{2}$
}

${ }^{1}$ Department of Fisheries Science, College of Fisheries Engineering, Tamil Nadu Dr. J. Jayalalithaa Fisheries University, Nagapattinam, Tamil Nadu, India

2 Tamil Nadu Dr. J. Jayalalithaa Fisheries University, Nagapattinam, Tamil Nadu, India

${ }^{3}$ Fisheries College and Research Institute, Tuticorin, Tamil Nadu, India

Key words: Biofloc, Penaeus vannamei, carbon source, C:N ratio, proximate composition, heterotrophic bacteria

\begin{abstract}
In the biofloc systems the continuous application of carbon sources led to the assimilation of nitrogenous nutrients and formation of heterotrophic bacterial biomass. The present experiment was conducted in $0.22 \mathrm{~m}^{3}$ capacity tanks in the triplicate to find out the structure, proximate composition, nutrient dynamics and growth characteristics of Penaeus vannamei in indoor biofloc systems with three different salinities (35, 20 and 5ppt) and carbon sources (molasses, sugar and rice flour) with an estimated $\mathrm{C}: \mathrm{N}$ ratio of $15: 1$. pre salinity acclimatized $P$. vannamei, specific pathogen free seeds $(0.2 \pm 0.04 \mathrm{~g})$ were stocked $@ 100$ numbers per $\mathrm{m}^{3}$ and fed 4 times a day based on the \% of body weight (from $22 \%$ to $2.5 \%$ ) and reared for 10 weeks. The results revealed that the carbon application at different salinities significantly influenced the biofloc structure (Scanning Electron Microscopic images of biofloc 4000x) showed round and rod-shaped structures. Proximate composition: crude protein $(p<0.001)$, ether extract $(p<0.001)$ and crude fibre $(p<0.05)$ showed significant difference between treatments. Similarly, elemental carbon composition $(p<0.01)$, nitrogenous waste assimilation of TAN $(p<0.01)$, nitrite $(p<0.05)$, and nitrate $(p<0.05)$ showed significant differences in the treatments vs. the control group. The variables also influenced the microbiota abundance the metagenomics analysis of biofloc showed Bray-Curtis overall average dissimilarity index of $81 \%$, and it varied from $49 \%$ to $100 \%$ between treatments \& controls \} and growth characteristics \{average body weight $(p<0.001)$ and survival rate $(p<0.01)$ between treatments and controls $\}$ of $P$. vannamei indoor biofloc systems. Hence, the application of carbon sources at different salinities influenced the biofloc structure, proximate, elemental carbon composition, biofloc microbiota abundance, enhanced the nitrogenous waste assimilation and growth performance of $P$. vannamei in indoor biofloc systems.
\end{abstract}

* Corresponding author. Tel.: 9952557799, e-mail: marine1anand@gmail.com tanand@tnfu.ac.in 


\section{Introduction}

Aquaculture paves the way for meeting the protein demand for the surging population worldwide. The world fish production was 179 million tons during the year 2018, out of which $46 \%$ was the share from aquaculture sector. There were many new technologies developed to improve productivity in aquaculture systems. One among that is biofloc technology (BFT), in which the nitrogenous wastes arising out of uneaten feed, fecal matter of cultured animal in the aquaculture systems, are converted into heterotrophic bacterial biomass by adding sufficient carbon sources. The biofloc are developed and sustained by continually adding the carbon sources depending upon the $\mathrm{C}: \mathrm{N}$ ratio of the feed and the TAN level of the biofloc systems (BFS) (Avnimelech, 1999).

In BFS, the organic wastes are converted into heterotrophic bacterial biomass thereby reduces the toxic nitrogenous wastes, which resulted in optimal water quality for the $P$. vannamei farming (Santhanakumar et al., 2018). The morphometric characteristics and the nutritional composition of biofloc depend upon the environmental conditions viz., temperature, salinity, dissolved oxygen, carbon source used, carbon loading rate and aeration intensity (Avnimelech, 2009). The total ammoniacal nitrogen (TAN level) and C:N ratio of BFS are the two critical parameters for the development \& sustenance of biofloc. Various carbon sources were used to maintain the $\mathrm{C} / \mathrm{N}$ ratio in the biofloc shrimp culture systems are molasses, tapioca flour, rice bran, wheat bran, sugar cane molasses, glucose, sucrose, corn flour, sugar, starch, wheat flour, rice flour, dextrose, glycerol and starch (Wei et al., 2016). The C:N ratio of the BFS above 10:1 is considered as optimum, but many authors suggested to maintain the C:N ratio of 15:1 (Panigrahi et al., 2019). The quality of biofloc is determined by its proximate composition viz., protein, fat, fiber, amino acids profile and fatty acid profile. There are many published reports on farming of $P$. vannamei in BFS. However, there are scanty of information on elemental carbon composition and structure of biofloc with various salinity range and carbon sources. Hence, the present experiment was conducted to find out the structure, proximate, elemental carbon composition, nutrient dynamics and growth characteristics of $P$. vannamei in indoor BFS with an estimated carbon to nitrogen ratio of $15: 1$, with three different salinities (35, 20 \& 5ppt) and carbon sources (molasses, sugar and rice flour).

\section{Experimental Set up}

\section{Materials and Methods}

An experiment was designed in a $3 \times 4$ factorial design wherein three different salinities $(35,20 \& 5 p p t)$ three different carbon sources (molasses, sugar and rice flour) and Control without carbon source for each salinity in triplicates were used for rearing $P$. vannamei for the period of ten weeks at the indoor wet laboratory of College of Fisheries Engineering, Vettar River View campus, Tamilnadu Dr. J. Jayalalithaa Fisheries University, Nagapattinam, Tamilnadu India (Table 1). The cylindrical tanks with the dimension of 120 $\mathrm{cm}$ high and $60 \mathrm{~cm}$ diameter with a capacity to hold $0.22 \mathrm{~m}^{3}$ were used in the experiment.

Table 1 Experiment Set up

\begin{tabular}{|ll|ll|ll|}
\hline \multicolumn{2}{|c|}{35 ppt treatment group } & \multicolumn{2}{c|}{20 ppt treatment group } & \multicolumn{2}{c|}{5 ppt treatment group } \\
\hline Molasses & $(\mathrm{T} 35 \mathrm{M})$ & Molasses & $(\mathrm{T} 20 \mathrm{M})$ & Molasses & $($ T5M) \\
\hline Sugar & $(\mathrm{T} 35 \mathrm{~S})$ & Sugar & $(\mathrm{T} 20 \mathrm{~S})$ & Sugar & $($ T5S) \\
\hline Rice flour & $(\mathrm{T} 35 \mathrm{R})$ & Rice flour & $(\mathrm{T} 20 \mathrm{R})$ & Rice flour & $(\mathrm{T} 5 \mathrm{R})$ \\
Control & $(\mathrm{C} 35)$ & Control & $(\mathrm{C} 20)$ & Control & $(\mathrm{C} 5)$ \\
\hline
\end{tabular}

The seawater with 35ppt for the experiment, was drawn from the Vettar estuary in Nagapattinam. The water was pumped into reservoir tanks through filtration (150-250 $\mu \mathrm{m}$ mesh size) and diluted with 1ppt bore water to get 20 and $5 p$ pt water. The tanks were bleached with calcium hypochlorite ( $35 \%$ concentration of chlorine) to attain a minimum residual chlorine concentration of $10 \mathrm{ppm}$ to kill the disease carriers, if existed in the experimental tanks., (International Office of Epizootics, 2009). The water was left for a week and then residual chlorine level was checked and sodium thiosulphate was added 
( $7 \mathrm{mg} / \mathrm{I}$ for each $1 \mathrm{mg} / \mathrm{l}$ of residual chlorine) (Van Wyk and Scarpa, 1999). The water from reservoir tanks were pumped into the experimental tanks and fertilized with dolomite at $10 \mathrm{~g} / \mathrm{m}^{3}$, superphosphate $15 \mathrm{~g} / \mathrm{m}^{3}$ and urea $15 \mathrm{~g} / \mathrm{m}^{3}$ for both treatment and control tanks for 2 to 3 days (Panigrahi et al., 2018). Fifty litres of appropriate saline water were autoclaved to that feed, respective carbon sources (molasses, sugar and rice flour) for each treatment were added then aerated for a day and applied uniformly to all the treatment tanks only for five days (Panigrahi et al., 2018). The free and bound carbohydrates and total carbohydrates present in the carbon sources are given in Table 2. The carbon to nitrogen ratio of the feed was $7: 1$. To bring the estimated $C / N$ to $15: 1$, for $1 \mathrm{~g}$ of added feed, $0.347 \mathrm{~g}$ of sugar, $0.368 \mathrm{~g}$ of molasses and $0.391 \mathrm{~g}$ of rice flour were added (Avnimelech, 2009; Panigrahi et al., 2019). Sugar and molasses as carbon source were added directly into the tanks by mixing with appropriate salinity water of the tanks whereas, rice flour was fermented before a day of application (Romano et al., 2018). The carbon sources were added everyday between 8 to 9am to the treatment tanks based on the status of $\mathrm{C}: \mathrm{N}$ ratio in the feed and total ammoniacal nitrogen (TAN) level was also taken into consideration to adjust the carbon dosage to experimental tanks to aid the formation of biofloc (Avnimelech, 1999; Panigarahi et al., 2018). To compensate the evaporation loss and to maintain the salinity at the specified level, once in a week an appropriate saline water was added into experimental tanks. After 20 days the control tanks were given a $10 \%$ exchange of total volume for once in a week to maintain the water quality.

Table 2 Composition of carbon sources used in the experiment

\begin{tabular}{|l|l|l|l|l|}
\hline S.No. & \multicolumn{1}{|c|}{ Carbon source } & $\begin{array}{c}\text { Free } \\
\text { Carbohydrates } \\
(\mathrm{g} \%)\end{array}$ & $\begin{array}{c}\text { Bound } \\
\text { Carbohydrates } \\
(\mathrm{g} \%)\end{array}$ & $\begin{array}{c}\text { Total } \\
\text { Carbohydrates }\end{array}$ \\
\hline 1 & Sugar & 96.8 & 0 & 96.8 \\
\hline 2 & Molasses & 91.4 & 0 & 91.4 \\
\hline 3 & Rice flour & 25.5 & 60.41 & $85.91^{*}$ \\
\hline${ }^{*}$ After fermenting $85.9 \%$ become free carbohydrates \\
\hline
\end{tabular}

Shrimp post larvae stocking, feeding and management of biofloc

Specific-pathogen-free $P$. vannamei post-larvae $(0.20 \pm 0.04 \mathrm{~g})$ procured from BMR hatchery, Tamil Nadu, India. The seeds were acclimatized and fed with commercial $P$. vannamei feed (1.8 to $3 \mathrm{~mm}$ feeds). In the BFS, once total suspended solids (TSS) reached $100 \mathrm{mg} / \mathrm{l}$ the tanks were stocked with pre-salinity acclimatized $P$. vannamei post larvae at the stocking density of 100 individuals per $\mathrm{m}^{3}$., (Criales et al., 2011). The proximate composition of the feed used in the experiment was as followed protein, $35.12 \%$, fat $10.21 \%$; crude fibre, 3.33\%; total ash, 9.1\%; nitrogen free extract, $36.44 \%$ and moisture $5.8 \%$. The shrimps were fed from $22 \%$ to $2.5 \%$ of average body weight (ABW) (Van Wyk, 1999). The quantity of feed was divided equally and fed four times a day for every four hours from morning 6am to till the end of the experiment (Rajkumar et al., 2015). Water quality analysis

Physicochemical parameters of water were analyzed at weekly intervals for entire duration of experiment. between 8am and 9am. The water samples from the experimental tanks were collected between $8 \mathrm{am}$ and $9 \mathrm{am}$. The parameters like $\mathrm{pH}$, dissolved oxygen (DO), salinity and temperature were measured daily 6am and 6pm (HANNA HI 9829 Multiparameter) in the experimental unit itself. Standard methods (APHA, 2005) were used for the analysis of $\mathrm{DO}$ and Total alkalinity (TA). TAN, $\mathrm{NO}_{2}-\mathrm{N}, \mathrm{NO}_{3}-\mathrm{N}$ and $\mathrm{PO}_{4}-\mathrm{P}$ were analyzed spectrophotometrically (UV LAMBDA 25 PERKIN ELMER) by using the GF/C filtered water samples. Filtered materials used for total suspended solids analysis by following the standard methods (APHA, 2005). 


\section{Enumeration of Total heterotrophic counts (THC)}

The water samples were collected aseptically for the enumeration of Total Heterotrophic Counts Water (THC) once a week, and also the wet biofloc samples from the Imhoff cone were collected aseptically for total heterotrophic counts of biofloc (THCB). The samples were inoculated using the spread plate method and incubated at $37^{\circ} \mathrm{C}$ for 48 hours after inoculation. Colonies in the range of 30 to 300 were counted and expressed as bacterial colony forming units (CFU/ml) by following the standard methods (APHA, 2005).

\section{Biofloc volume and estimation of proximate composition of biofloc}

The Imhoff cone made by Merck, Mumbai, Maharashtra, India, was used for the measurement of biofloc volume (BFV) and an inverted light microscope (OLYMPUS, Model CKX 41/C1, Make-Japan) was used to examine the floc structure. At the end of the experiment, the biofloc samples were collected from Imhoff cone and dried in an oven at $60^{\circ} \mathrm{C}$ then the proximate composition of the same was analysed using standard methods (AOAC, 1995). The crude protein (CP) content of biofloc samples were measured by following the Kjeldahl method (Kelplus ULTIMADUODST-TS-E Automatic Protein Estimation System), crude lipid by automatic fat extraction system (Socsplus-SCS08R fat extraction), crude fibre by automatic fiber analysis system (Fibraplus-FES08R, C-13009). The Ash content also measured by using the standard methods and nitrogen- free extract was calculated (AOAC, 1995).

\section{Biofloc structure using high resolution scanning electron microscopy}

The biofloc samples from the experimental tanks were collected and fixatives were added in the biosafety cabinets and appropriate saline water was used to reduce the damage and kept in the fridge till the analysis, At the time of analysis the samples were prepared for scanning electron microscopy and mapping (SEM-EDS mapping) based on the protocols and guidelines given by Murtey and Ramasamy (2016). The biofloc samples were analysed using High - resolution scanning electron microscope (HR-SEM - FEI Quanta FEG 200). As per the guidelines of Newbury and Ritchie (2012) the results of HRSEM-EDS mapping could be taken up for quantitative comparison.

DNA extraction, PCR amplification of $16 S$ rRNA genes and next-generation sequencing

The biofloc samples settled in the Imhoff cone from triplicate tanks were collected and mixed together for each treatment and the DNA extraction was carried out as per the procedures given by Deng et al., (2018) by using Oxford Nanopore kit. The bacterial composition of each sample was studied by using a barcoded sequencing approach. The details of primers used during the amplification process are given in Table $\mathbf{3}$.

Table 3 Primers selected for PCR

\begin{tabular}{|l|l|l|}
\hline \multicolumn{1}{|c|}{ Primer Name } & \multicolumn{1}{c|}{ Sequence Details } & \multicolumn{1}{c|}{ References } \\
\hline 27F & 5'AGAGTTTGATCMTGGCTCAG3' & Heuer et al., (1997). \\
\hline 1492R & 5'AAGGAGGTGATCCAGCCGCA3' & Heuer et al., (1997). \\
\hline ITS1 & 5'TCCGTAGGTGAACCTGCGG3' & Tedersoo et al., (2015) \\
\hline ITS1 & 5'TCCTCCGCTTATTGATATGC3' & Tedersoo et al., (2015) \\
\hline
\end{tabular}

The sequences after PCR amplification were then sent to Acobiom laboratory at Montpellier, France, for generation of libraries, using the MiSeq Illumina genome sequencer (300 cycles). EPI2ME 16S analysis workflow allows users to perform genus-level identification from single reads; The EPI2ME platform was used and the FASTQ files were uploaded in the said platform to get the quality reads. The raw sequences generated were uploaded to the BLAST tool of NCBI for the sequence similarity test with the other $16 \mathrm{~S}$ sequences present in Genbank database. The reads were classified upon the percentage of coverage and identity (Deshpande et al., 2019). 
The metagenomics database was submitted to National Centre for Biotechnology Information (NCBI) as a bio project entitled "Metagenomics of biofloc from P. vannamei biofloc culture systems with different salinity and carbon sources (2020)" (Bio project accession no: PRJNA663309).

Statistical tools used for analysis of the experimental results

All statistical analysis was conducted by using PAST 4.02 software for Windows (Hammer et al., 2001). Repeated measures ANOVA with post hoc Tukey's tests were used for comparison of water quality parameters.

\section{Results}

Water quality and nutrient dynamics of the biofloc systems

Significant differences ( $p>0.05)$ were not observed in the temperature and DO levels of treatments and control. The $\mathrm{pH}$ value recorded during morning and evening varied significantly $(p<0.05)$ between the treatment groups and control and within the treatment groups. The $\mathrm{pH}$, TA and TSS differ significantly $(\mathrm{p}<0.05)$ between the experimental groups. Significant differences $(p<0.01)$ were found in the TAN (Figure 1 a-c), $\mathrm{NO}_{2}-\mathrm{N}$ (Figure 2 $\mathbf{a}-\mathbf{c}), \mathrm{NO}_{3}-\mathrm{N}$ (Figure $\mathbf{3}$ a-c), and $\mathrm{PO}_{4}-\mathrm{P}$ (Figure 4 a-c) values between the treatments and control in all the salinity groups. In general, the TAN and $\mathrm{NO}_{2}-\mathrm{N}$ values were lower in treatments than control in all the salinity groups. Significant difference was found in the TAN concentrations of molasses (5ppt showed significant difference with 35 and 20ppt), rice flour(significant difference between 35 and 5ppt) treated tanks but there was no significant differences in sugar treated tanks. In general, the nitrate values were recorded high in the control than in the treatments in all salinity groups. The significant difference $(p<0.01)$ in the THC values between BFS and controls also observed in the present experiment. Among the THC values in the water and biofloc of indoor $P$. vannamei systems the THCB was higher than the THC of water in the BFS (Figure $\mathbf{5} \mathbf{a}-\mathbf{c}$ ). The $\mathrm{PO}_{4}-\mathrm{P}$ values were higher in treatments than the control.
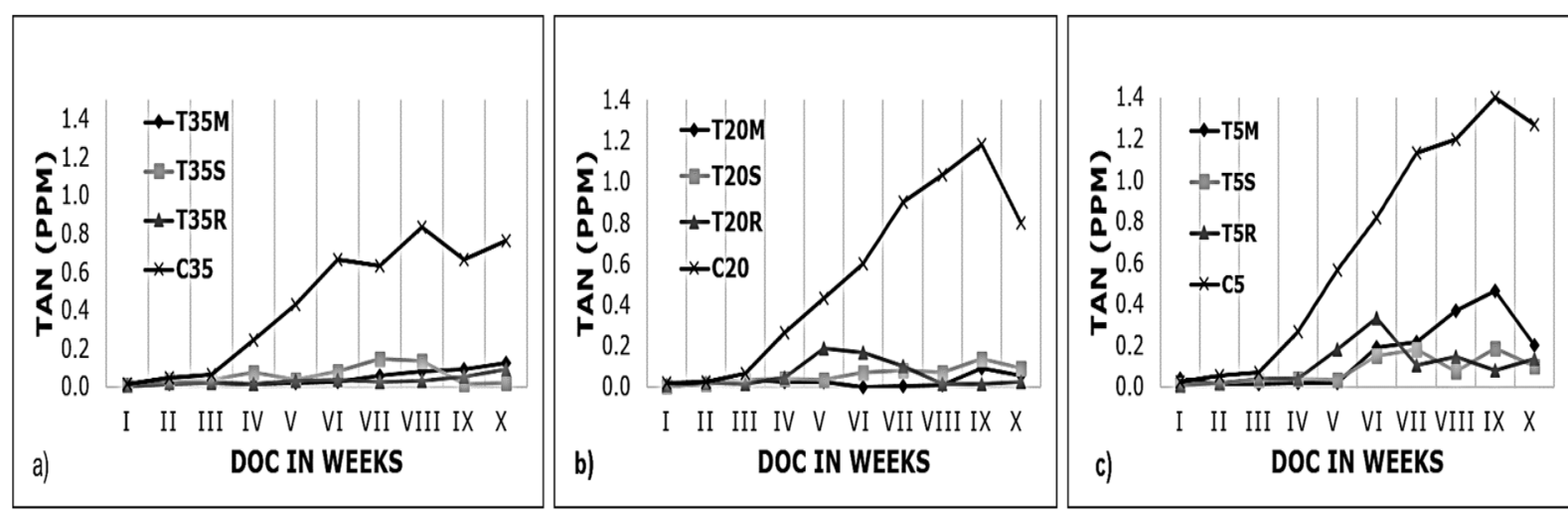

Figure 1 TAN level at a) 35ppt with molasses (T35M), sugar (T35S), rice flour(T35R) and control (C35) b) 20ppt with molasses(T20M), sugar (T20S), rice flour (T20R) and control (C20) c) 5ppt with molasses (T5M), sugar (T5S), rice flour (T5R) and control (C5)

Biofloc volume, structure, proximate and elemental carbon composition

The BFV differ significantly $(p<0.05)$ between different treatment groups. Irrespective of the carbon source the 5ppt treatment group showed the highest mean BFV than the other two salinity groups.

The SEM images of biofloc treatments showed the presence of round, cocci and rodshaped structure (Figure 6). Round shaped microbial communities significantly abundant in the biofloc groups than the control. The Bray-Curtis overall average dissimilarity index was $81 \%$ between the biofloc treatments and controls. The average dissimilarity index was more than $50 \%$ and up to $100 \%$ between control and treatments and within treatments of all salinity groups except T35S vs C35 (49\%) (Figure 7). 

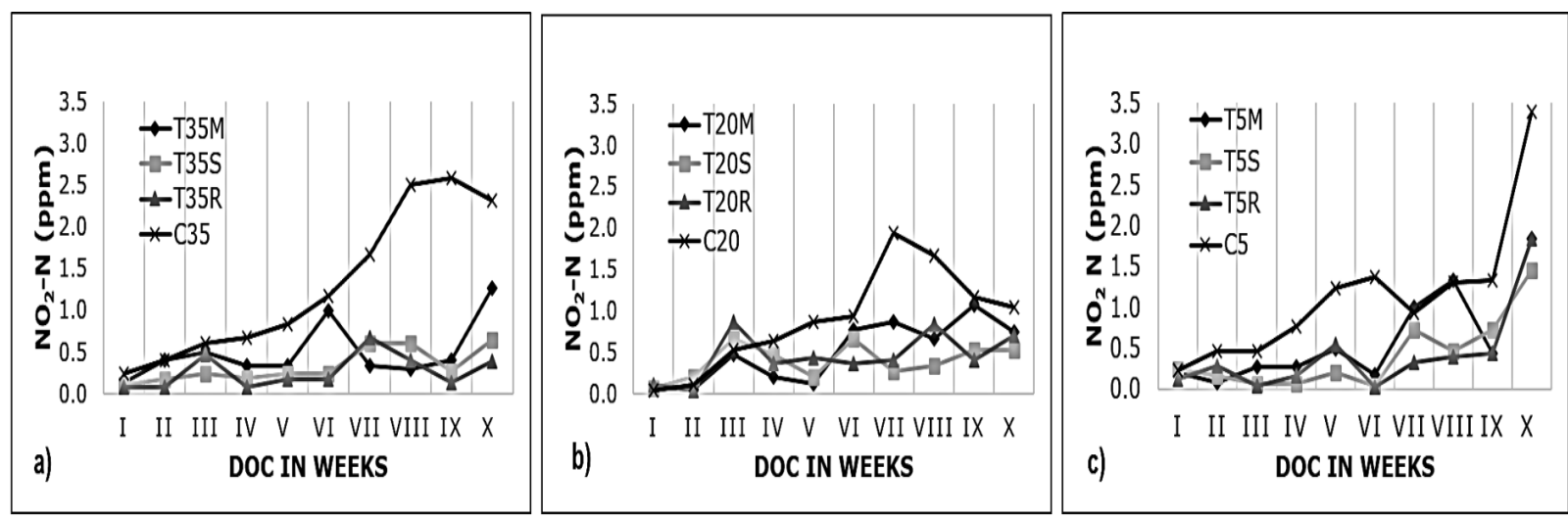

Figure 2 Nitrite nitrogen $\left(\mathrm{NO}_{2}-\mathrm{N}\right)$ level at a) 35ppt with molasses (T35M), sugar (T35S), rice flour (T35R) and control (C35) b) 20ppt with molasses (T20M), sugar (T20S), rice flour (T20R) and control (C20) c) $5 p p t$ with molasses (T5M), sugar (T5S), rice flour (T5R) and control (C5)
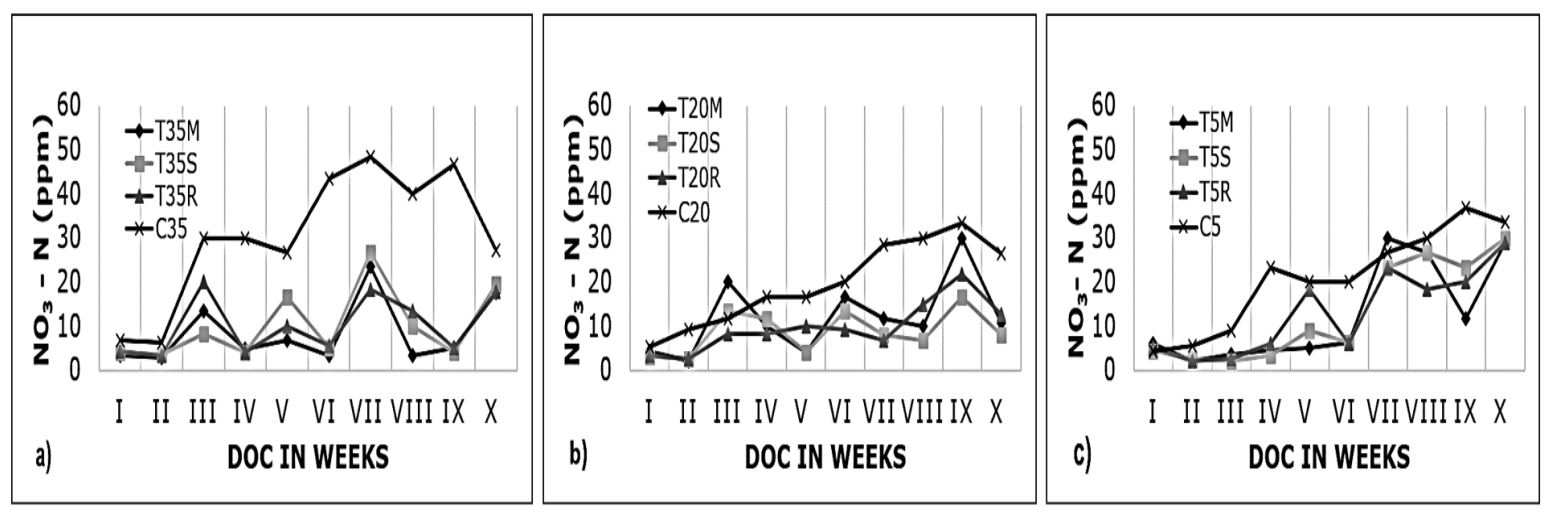

Figure 3 Nitrate nitrogen $\left(\mathrm{NO}_{3}-\mathrm{N}\right)$ level at a) 35ppt with molasses (T35M), sugar (T35S), rice flour (T35R) and control (C35) b) 20ppt with molasses (T20M), sugar (T20S), rice flour (T20R) and control (C20) c) 5ppt with molasses (T5M), sugar (T5S), rice flour (T5R) and control (C5)
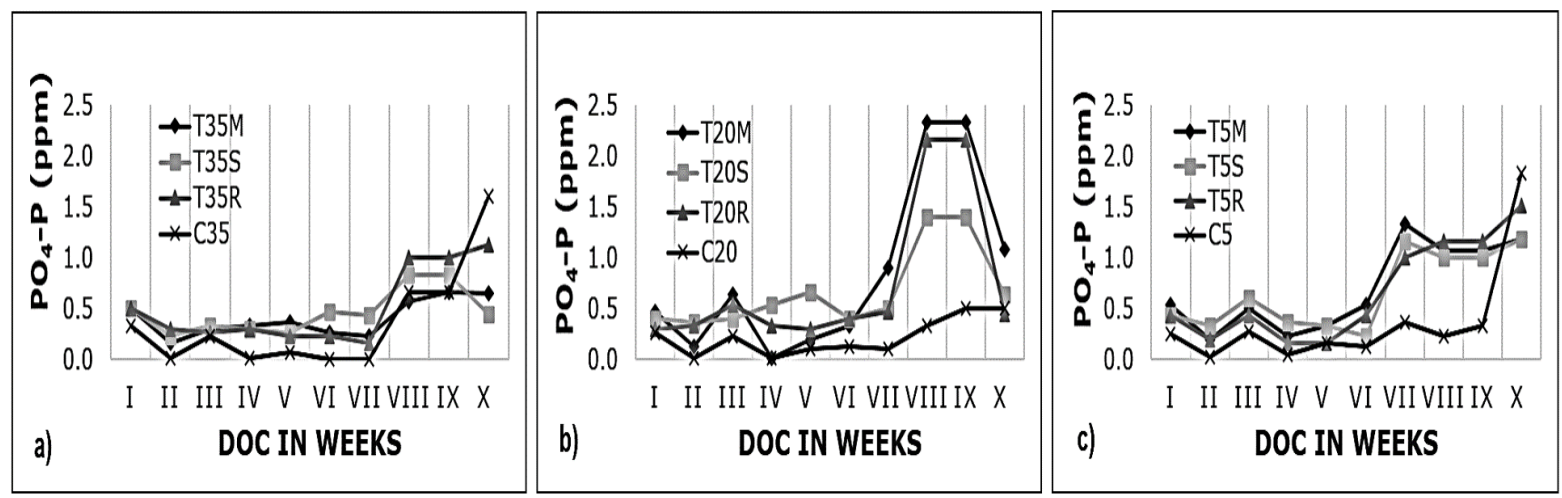

Figure 4 Phosphate Phosphorus $\left(\mathrm{PO}_{4}-\mathrm{P}\right)$ level at a) 35pt with molasses (T35M), sugar (T35S), rice flour (T35R) and control (C35) b) 20ppt with molasses (T20M), sugar (T20S), rice flour (T20R) and control (C20) c) 5ppt with molasses (T5M), sugar (T5S), rice flour (T5R) and control(C5) 

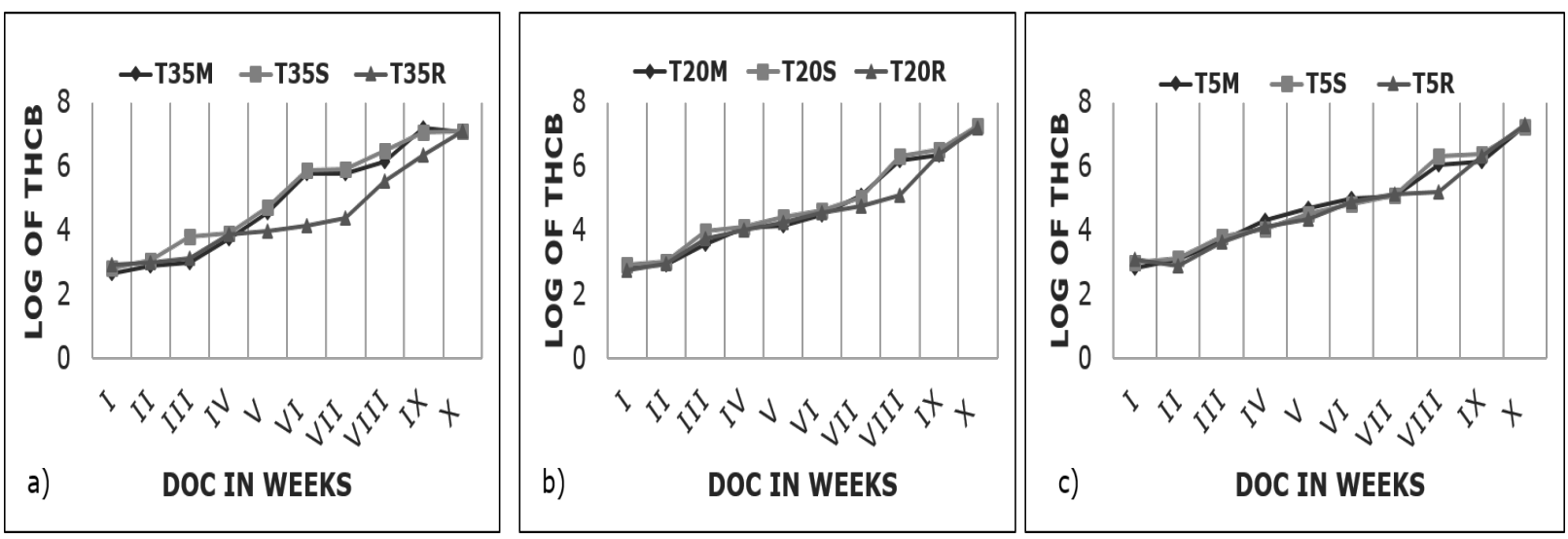

Figure 5 Total heterotrophic counts of biofloc (THCB) level at a) 35ppt with molasses (T35M), sugar (T35S), rice flour (T35R) and control (C35) b) 20ppt with molasses (T20M), sugar (T20S), rice flour (T20R) and control (C20) c) 5ppt with molasses (T5M), sugar (T5S), rice flour (T5R) and control (C5)
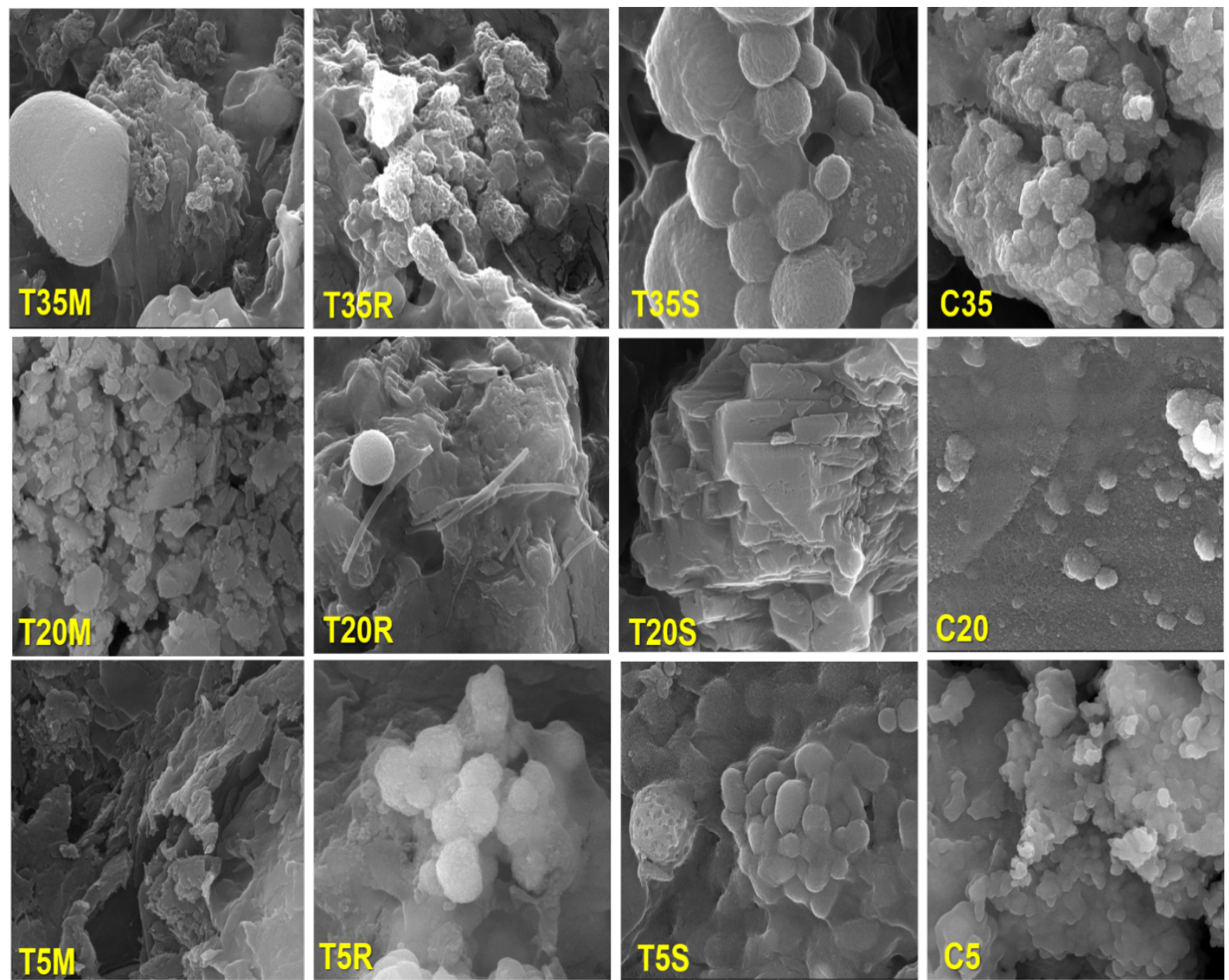

Figure 6 Scanning electron microscopy (4000x magnification) images of biofloc at different salinities with molasses (T35M, T20M and T5M), sugar (T35S, T20S and T5S), Rice flour (T35R, T20R and T5R) and images of controls without carbon sources (C35, C20 and C5) 


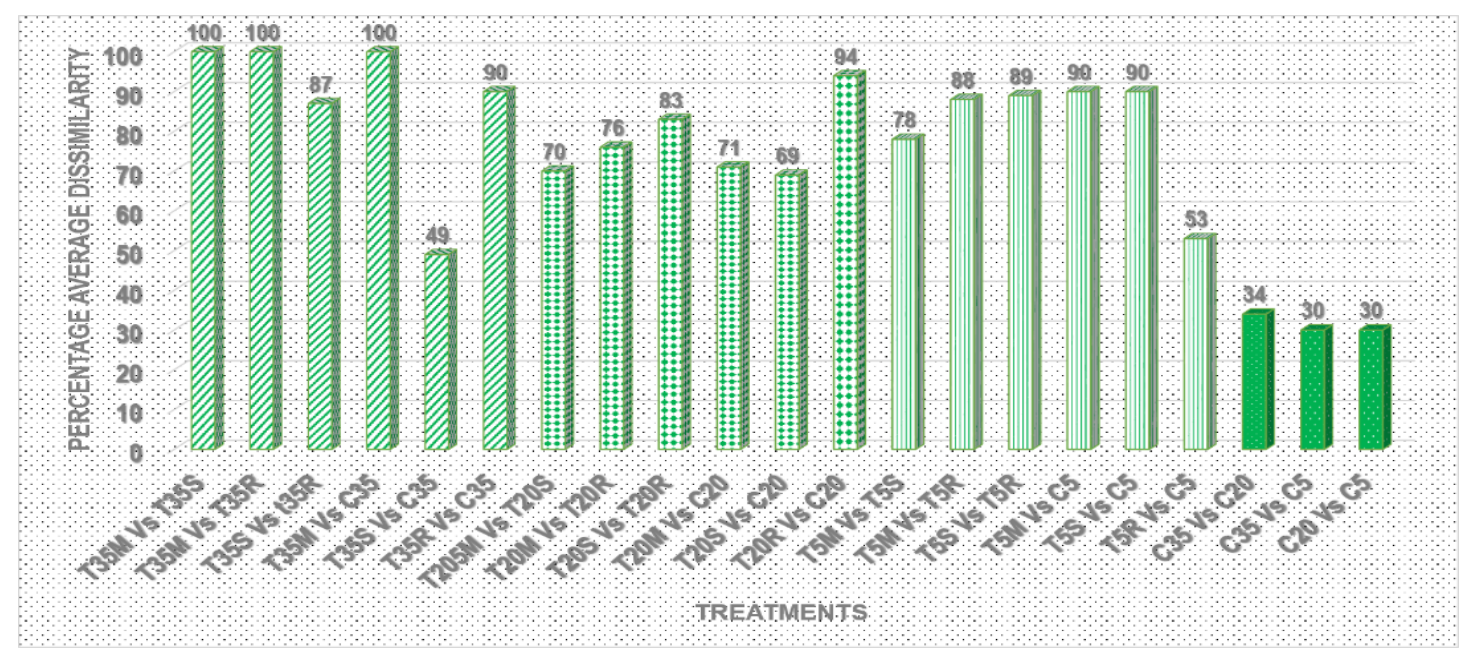

Figure 7 Average dissimilarity index of bacterial diversity based on Bray Curtis average dissimilarity index at different salinities with carbon sources

Note: In the Figure 9 W/ 35ppt treatment group, ${ }^{2}$ 20ppt treatment group, $⿴$ 5ppt treatment group, Control group

The proximate composition of biofloc is given in the Table 4. In the present investigation, crude protein ranged from $23.2 \pm 1.9$ to $39.18 \pm 3.4 \%$ among different

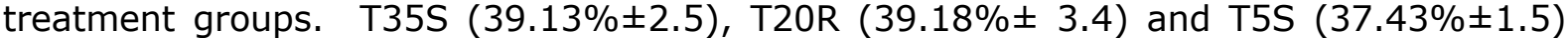
treatments had the highest CP content among the different treatment groups. The mean ether extract values ranged from $1.19 \% \pm 0.23$ to $4.23 \% \pm 0.62 \%$ in the biofloc of different treatments, which was highest in T35M $(4.23 \% \pm 0.62)$, T20S $(2.47 \% \pm 0.35)$ and T5S $(2.44 \% \pm 0.17)$ treatments. Crude fiber contents were ranged from $4.6 \pm 0.61$ to $20.9 \pm 0.44 \%$ in different biofloc treatments. However, it was observed that the mean crude fiber content values in different salinity groups with different carbon sources showed a significant difference $(p<0.05)$ between treatments and among treatments. Ash contents differ in different saline treatments and it was ranged from $6.5 \pm 0.21$ to $10.6 \pm 0.36 \%$. 


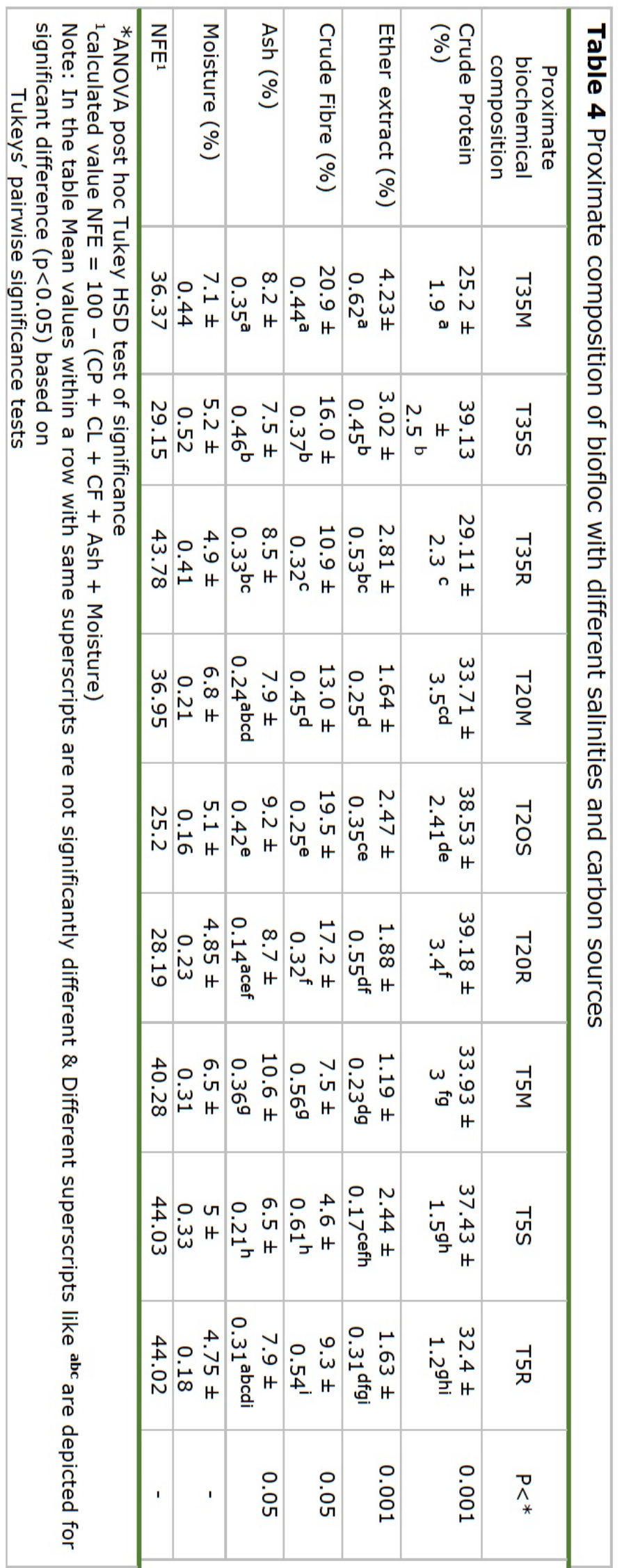

The Israeli Journal of Aquaculture - Bamidgeh • IJA.73.2021.1526990 
A significant difference $(p<0.05)$ was observed in the elemental carbon composition between different treatments and their respective controls based on the SEM-EDS distribution map results. In the present study, the carbon (wt.\%) was significantly higher in all the treatments (Figure $\mathbf{8}$ a-d, Figure $\mathbf{9}$ a-d and Figure $\mathbf{1 0}$ a-d) than that of controls.
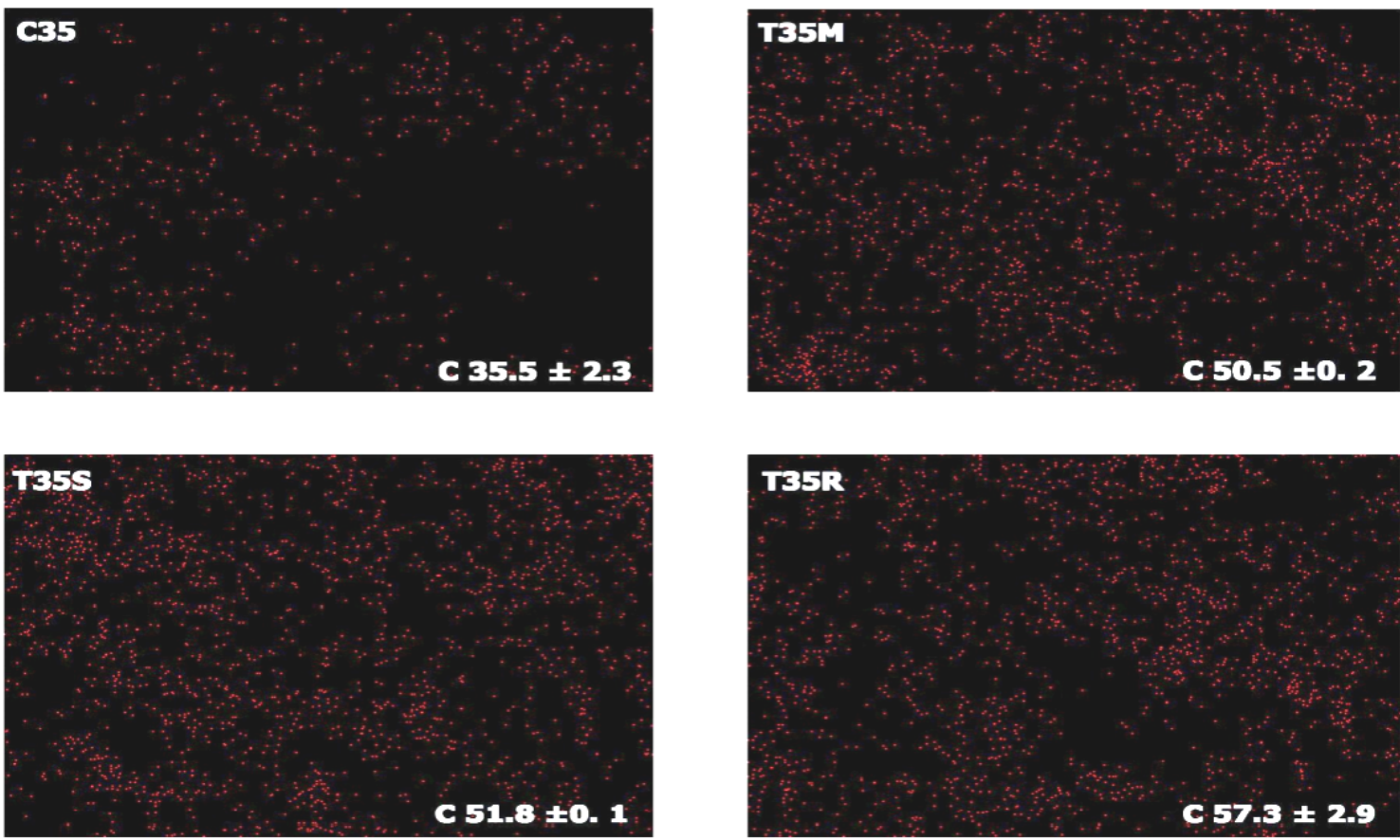

Figure 8 SEM-EDS images of elemental Carbon distribution in biofloc of treatments and control at 35ppt with molasses (T35M), sugar (T35S), rice flour (T35R) as carbon sources and controls (C35)
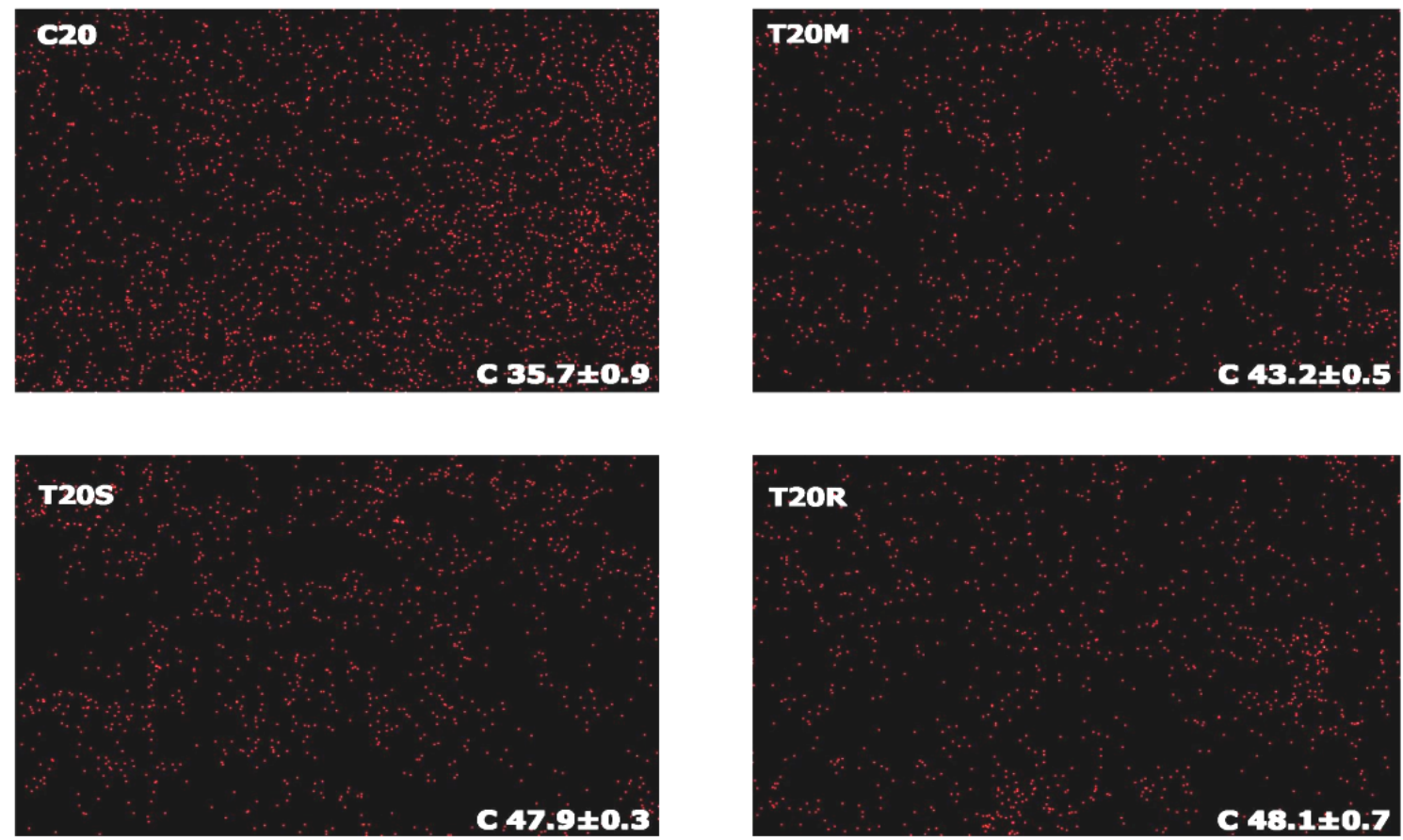

Figure 9 SEM-EDS images of elemental Carbon distribution in biofloc of treatments and control at 20ppt with molasses (T20M), sugar (T20S), rice flour (T20R) as carbon sources and controls (C20) 

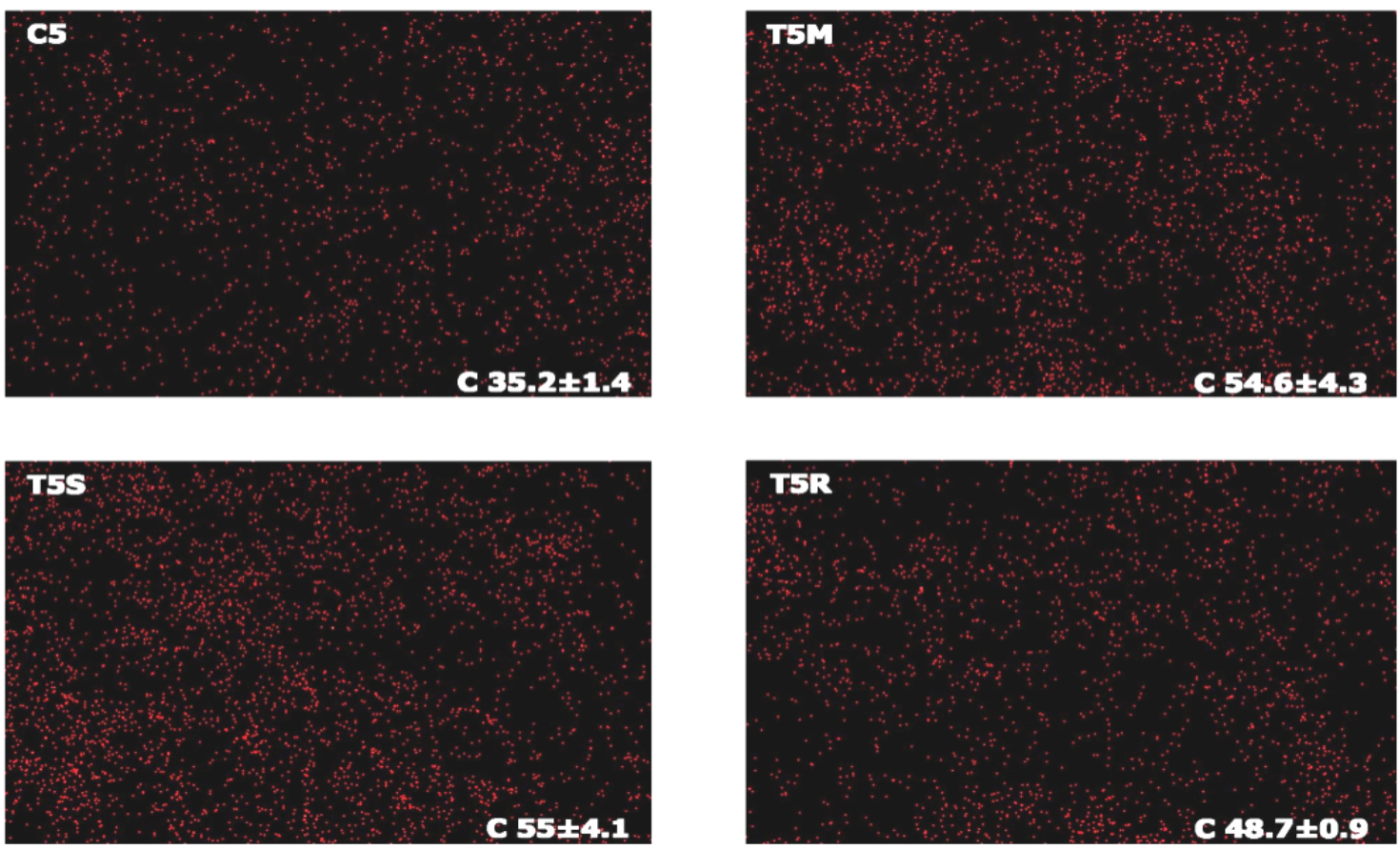

Figure 10 SEM-EDS images of elemental Carbon distribution in biofloc of treatments and control at 5 ppt with molasses (T5M), sugar (T5S), rice flour (T5R) as carbon sources and controls (C5)

\section{Growth characteristics}

In the present investigation, a significant difference in growth performance and survival was observed between the treatments and controls (Table 5). Among different treatments sugar treated experiment tanks showed better growth than other treatments. Hence, the higher crude protein content in BFS was positively influenced the ABW of the cultured shrimp. The survival rate was lower in low saline treatments. However, the moderate 20ppt salinity showed both good growth and survival rate than other two salinities. 


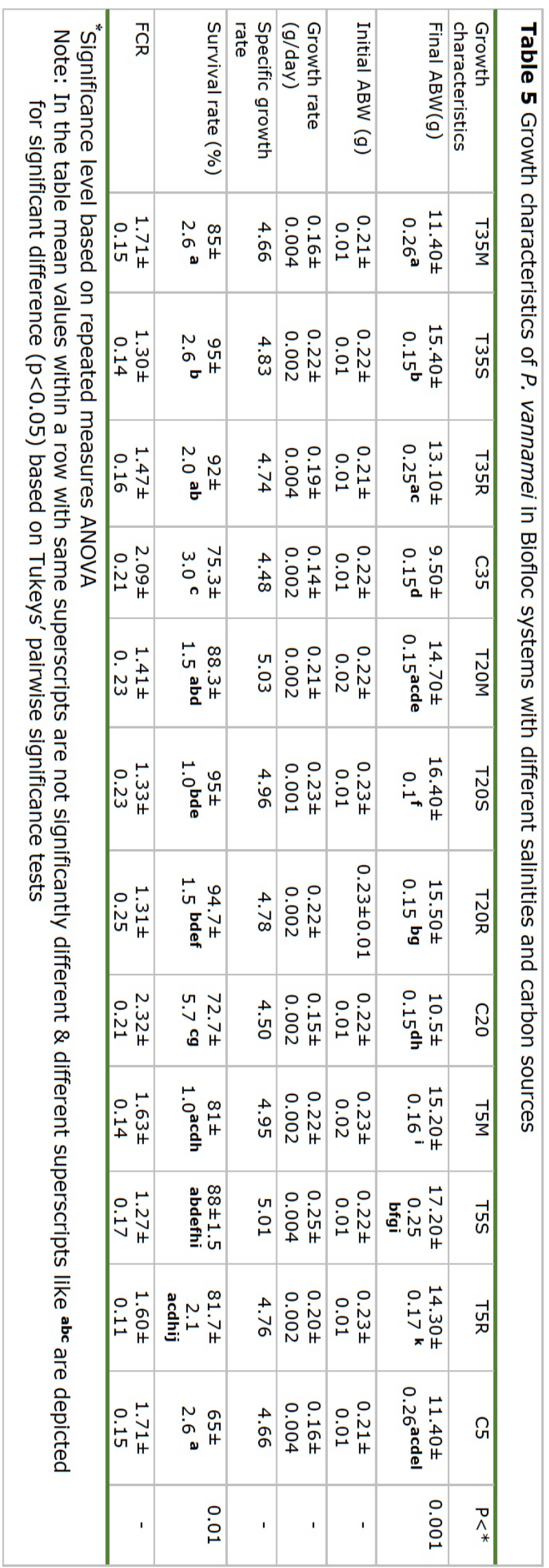




\section{Discussion}

Water quality and nutrient dynamics of biofloc systems

The water quality parameters of any aquaculture systems depended upon many factors viz., prevailing environmental conditions, species cultured, culture intensity, stocking density, feeds and other inputs used in the culture, their quantity and quality (Panigrahi et al., 2018). The DO, temperature, $\mathrm{pH}, \mathrm{TA}$ and TSS were within the optimum range for growing P. vannamei in the present experiment (Van Wyk and Scarpa, 1999; Emerenciano et al., 2017). The temperature being the major factor in microbial metabolism as very high and low temperatures could affect the floc formation. The TAN and nitrite values were within the safety levels for growing $P$. vannamei at different salinities (Van Wyk and Scarpa, 1999). The differences in the $\mathrm{NO}_{2}-\mathrm{N}, \mathrm{NO}_{3}-\mathrm{N} \&$ TAN values between the control and different treatments exhibited the assimilation of nitrogenous wastes by the heterotrophic biomass in the BFS (Da Silva et al., 2013). The significant difference $(p<0.01)$ in the THC values between BFS and controls also evinced the fact very well. However, among the THC water and THC of biofloc the THCB served as an indicator of systems efficiency than the THC of water. The accumulation of $\mathrm{PO}_{4}-\mathrm{P}$ in BFS showed that the lower capability of heterotrophic biomass in the assimilation of the PO4-P and it is in accordance with the earlier experiments conducted hence, periodic removal of $\mathrm{PO}_{4}-\mathrm{P}$ is necessary in high density BFS (Panigrahi et al., 2019).

\section{Biofloc volume, structure, proximate and elemental carbon composition}

The literature about the SEM image of biofloc and elemental carbon of biofloc are scanty. Round, cocci and rod shaped biofloc structures were found from the SEM images with 4000x magnification. The structure of the organisms in the biofloc influenced by the salinity and carbon sources since the change in salinity and carbon sources influenced the microbiota diversity of biofloc (Kirchman et al., 2001; Deng et al., 2018). Though the biofloc are the conglomerates of heterotrophic bacteria, protozoa and algae, whereas at higher $\mathrm{C}: \mathrm{N}$ ratios the microbiota mostly dominated by heterotrophic bacteria. In the present experiment, at the maintained C:N ratio of $15: 1$ biofloc mostly dominated by heterotrophic bacteria (Guo et al., 2020). Though the structure in SEM images of biofloc showed mostly round shaped colonies, the microbial communities in the biofloc treatments showed significant differences in the abundances than that of controls based on the BrayCurtis overall average dissimilarity index ( $81 \%)$. The average dissimilarity index was more than $50 \%$ and up to $100 \%$ between control and treatments and within treatments of all salinity groups, which clearly indicated the differences in the microbial abundance of treatments and controls. Hence, due to the application of carbon sources at different salinities the heterotrophic microbiota in the biofloc showed variation in the abundance (Deng et al., 2018).

The composition of biofloc varied with the level of inputs applied i.e., feed, fertilizers, carbon source, carbon loading rates, protein content in the feed and environmental conditions. However, the change in the carbon sources, affect the proximate composition of biofloc. The CP and lipid values of biofloc in the present experiment were in the range as mentioned by other researchers (Emerenciano et al., 2017). However, in certain experiments, it was reported higher CP content above $45 \%$ (Promthale and Boonsirm, 2019). Irrespective of the salinity the sugar as carbon source showed consistent crude protein content ranging from $37.43 \pm 1.5$ to $39.13 \pm 2.5 \%$. At $20 \mathrm{ppt}$ sugar and rice flour showed almost comparable CP content. Hence, at 35ppt and 5ppt sugar can be used as a carbon source, at 20ppt sugar and rice flour can be used alternatively. In the present investigation, the carbon sources were influenced the crude fiber content which is in accordance with earlier studies, as well as the salinity influenced the crude fiber contents. Ash content of biofloc varied with the salinity and carbon sources used (Wei et al., 2016).

The literature on the elemental composition of biofloc is scanty. However, in the present study, the carbon (wt.\%) was significantly higher in all the treatments than the controls (Newbury and Ritchie 2012). This finding confirmed the fact that the elemental carbon composition of bacterial biomass reflected the source conditions under which they were 
grown (Fagerbakke et al., 1996). Hence, the carbon enriched heterotrophic bacteria in BFS showed higher carbon content than controls. It was also found that at higher salinities (35 and 20ppt), carbon assimilation was in ascending order for carbon source i.e., molasses, sugar and rice flour (simpler to complex carbon sources) whereas at lower salinity (5ppt) it was in the reverse trend. The carbon content of the bacterial biomass was the deciding factor in the assimilation of nitrogenous wastes and formation of heterotrophic bacterial biomass.

\section{Growth characteristics}

The Biofloc treatments showed significantly higher growth and survival rate than that of controls. However, among the treatments sugar treated experiment tanks showed good growth than other treatments (Xu et al., 2013). Studies conducted with tapioca and wheat flour showed better growth characteristics (Rajkumar et al., 2015). From the present experiment it was also found that the higher crude protein content in the biofloc supported the growth of animal under culture. The survival rate was increasing with increase in the salinity. However, both average body weight and survival rate was higher at moderate 20ppt salinity than other two salinities. it may be due to the fact that the iso-osmotic point of $P$. vannamei is close to that of moderate salinity (20ppt) (Castile and Lawrence, 1981).

\section{Conclusions}

The biofloc structure, proximate, elemental carbon composition, nutrient dynamics, microbiota abundance in the biofloc and growth characteristics of $P$. vannamei are significantly influenced by the carbon sources used under different salinity conditions. The application of carbon sources influenced elemental carbon composition of the heterotrophic bacterial biomass, which was manifested from the SEM images and distribution maps. The SEM images showed round, cocci and rod-shaped structure of microbiota in the biofloc. The heterotrophic microbial communities in the biofloc showed higher variation in the abundance in different treatments and was manifested by the Bray Curtis overall average dissimilarity index of $81 \%$. The biofloc proximate composition also influenced by the carbon sources applied and sugar performed better with higher crude protein content at higher salinities ( $35 \& 20 \mathrm{ppt}$ ) followed by rice flour and molasses. The ABW and survival rate was higher in sugar treated tanks whereas among salinities at 20ppt both ABW and survival rate was higher. From the present experiment it was found that the structure, proximate composition, elemental carbon composition, microbiota abundance in the biofloc, nitrogen assimilation and growth characteristics of $P$. vannamei was influenced by the carbon sources under different salinity conditions in the biofloc systems and sugar can be used as a carbon source irrespective of salinities.

\section{Acknowledgements}

This research was carried out as partial fulfillment of the Ph.D. program at Tamilnadu Dr. J. Jayalalithaa Fisheries University, Nagapattinam. The author thanks Tamilnadu Dr. J. Jayalalithaa Fisheries University, Nagapattinam, Tamilnadu, India, for the funding support rendered for completing the Ph.D. work.

\section{References}

Association of Official Analytical Chemists (A.O.A.C) 1990. Official Methods of Analysis. 15th Edition, Association of Official Analytical Chemist, Washington DC. Pp. 771

American Public Health Association (APHA), 2005. Standard Methods of Examination of Water and Wastewater, (21 $1^{\text {st }}$ ed.) APHA, Washington, D.C.

Avnimelech Y., 1999. C/N ratio as a control element in aquaculture systems. Aquaculture 176:227-235. doi.org/10.1016/S0044-8486(99)00085-X

Avnimelech Y., 2009. Biofloc Technology-A Practical Guide Book. The World Aquaculture Society, Baton Rouge, Louisiana, United States. 182 pp. ISBN: 9781888807165. 
Castile F.L. and A.L. Lawrence, 1981. The effect of salinity on the osmotic, sodium and chloride concentrations in the haemolymph of euryhaline shrimp of the genus Penaeus. Comparative Biochemistry \& Physiology, 68A:75-80. doi.org/10.1016/03009629(81)92563-9

Criales M., Zink I., Browder J. and T. Jackson, 2011. The effect of acclimation salinity and age on the salinity tolerance of pink shrimp post larvae. Journal of Experimental Marine Biology and Ecology, 409(1-2): 283-289. doi.org/10.1016/j.jembe. 2011.09.007

Da Silva K.R., Wasielesky, W. and P.C. Abreu, 2013. Nitrogen and phosphorus dynamics in the biofloc production of the pacific white shrimp, Litopenaeus vannamei. Journal of World Aquaculture Society, 44(1): 30-41. doi.org/10.1111/jwas.12009

Deng M., Chen J., Gou J., Hou J., Li D. and X. He, 2018. The effect of different carbon sources on water quality, microbial community and structure of biofloc systems. Aquaculture, 482:103-110. doi.org/10.1016/j.aquaculture.2017.09.030

Deshpande V., Reed T.M., Sullivan R., Kerkhof L.J., Beigel K.M. and M.M. Wade, 2019. Offline Next Generation Metagenomics Sequence Analysis Using MinION Detection Software (MINDS). Genes basel, doi:10.3390/genes10080578

Emerenciano M., Martínez-Córdova L.R., Martínez-Porchas M. and A. MirandaBaeza, 2017. Biofloc Technology (BFT): A Tool for Water Quality Management. Aquaculture, doi:10.5772/66416

Fagerbakke K.M., Heldal M. and S. Norland, 1996. Content of carbon, nitrogen, oxygen, sulfur, and phosphorus in native aquatic and cultured bacteria. Aquatic Microbial Ecology, 10: 15-27. doi:10.3354/ame010015

Guo H., Huang L., Hu S., Chen C., Huang X., Liu W., Wang S., Zhu Y., Zhao Y. and D. Zhang, 2020. Effects of Carbon/Nitrogen Ratio on Growth, Intestinal Microbiota and Metabolome of Shrimp (Litopenaeus vannamei). Frontiers in Microbiology, doi.org/10.3389/fmicb.2020.00652

Hammer O., David A.T.H. and P.D. Ryan, 2001. Past: Paleontological Statistics Software Package for Education and Data Analysis. Palaeontologia Electronica. http://palaeoelectronica.org/2001_1/past/issue1_01.htm

Heuer H., Krsek M., Baker P., Smalla K. and E.M. Wellington, 1997. Analysis of actinomycete communities by specific amplification of genes encoding 16S rRNA and gel electrophoretic separation in denaturing gradients. Applied Environmental Microbiology, 63:3233-3241. DOI: 10.1128/aem.63.8.3233-3241.1997

International Office of Epizootics (OIE), 2009. Manual of diagnostic tests for aquatic animals. Paris, France.

Kirchman D., Yu, L.Y., Fuchs B.M. and R. Amann, 2001. Structure of bacterial communities in aquatic systems as revealed by filter PCR. Aquatic Microbial Ecology, 26: 13-22. Doi:10.3354/ame026013.

Murtey M.D. and P. Ramasamy, 2016. Sample preparations for scanning electron microscopy - life sciences. Modern Electron Microscopy in Physical and Life Sciences. doi: $10.5772 / 61720$.

Newbury D.E. and N.W.M. Ritchie, 2012. Is Scanning Electron Microscopy/Energy Dispersive X-ray Spectrometry (SEM/EDS) Quantitative? Scanning 35(3):141-168. DOI: 10.1002/sca.21041

Panigrahi A., Sundaram M., Chakrapani S., Satishkumar R., Syama Dayal J. and C. Gopal, 2019. Effect of carbon and nitrogen ratio (C:N) manipulation on the production performance and immunity of Pacific white shrimp Litopenaeus vannamei (Boone, 1931) in a biofloc-based rearing system. Aquaculture Research, 50:29-41. doi.org/10.1111/ are. 13857

Panigrahi A., Sundaram M., Saranya C., Sathish Kmar R., Syama Dayal J., Saraswathy R., Otta S.K., Shyne Anand P.S., Nila Rekha P. and C. Gopal, 2018. Influence of differential protein levels of feed on production performance and immune response of pacific white leg shrimp in a biofloc-based system. Aquaculture. doi.org/10.1016/j.aquaculture. 2018.12.036 
Promthale P.W. and W.K. Boonsirm, 2019. Biofloc substituted fishmeal feed stimulates immune response and protects shrimp from Vibrio parahaemolyticus infection. Fish and Shellfish Immunology, 93:1067-1075. DOI: 10.1016/j.fsi.2019.07.084

Rajkumar M., Pandey P.K., Aravind R., Vennila A., Bharti V. and C.S. Purushothaman, 2015. Effect of different biofloc systems on water quality, biofloc composition, and growth performance in Litopenaeus vannamei (Boone, 1931). Aquaculture Research, 47: 3432-3444. doi:10.1111/are.12792.

Romano N., Dauda A.B., Ikhsan N., Karim M. and M.S. Kamarudin, 2018. Fermenting rice bran as a carbon source for biofloc technology improved the water quality, growth, feeding efficiencies and biochemical composition of African catfish Clarias gariepinus juveniles. Aquaculture Research, 49:3691-3701. doi.org/10.1111/are.13837

Santhana Kumar V., Pandey P.K., Anand T., Bhuvaneswari G.R., Dhinakaran A. and S. Kumar, 2018. Biofloc improves water, effluent quality and growth parameters of Penaeus vannamei in an intensive culture system. Journal of Environmental Management, 215:206-215. DOI: 10.1016/j.jenvman.2018.03.015

Tedersoo L., Anslan S., Bahram M., Põlme S., Riit T., Liiv I., Kõljalg U., Kisand V., Nilsson R.H., Hildebrand F., Bork P. and K. Abarenkov, 2015. Shotgun metagenomes and multiple pair-barcode combinations of amplicons reveal biases in meta-barcoding analyses of fungi. MycoKeys, 10:1-43. doi.org/10.3897/ mycokeys. 10. 4852

Van Wyk P., 1999. Nutrition and Feeding of Litopenaeus vannamei in Intensive Culture Systems. 125-139. pp. In: P. Van Wyk, J. Scarpa, M. Davis-Hodgkins, R. Laramore, K. Main, J. Mountain (eds.) Farming marine shrimp in recirculating freshwater systems, Florida, USA. 220 pp

Van Wyk P. and J. Scarpa, 1999. Water quality requirements and management. pp. 141161. In: P. Van Wyk, J. Scarpa, M. Davis-Hodgkins, R. Laramore, K. Main, J. Mountain (eds.) Farming marine shrimp in recirculating freshwater systems, Florida, USA. 220 pp.

Wei Y., Liao S.A. and A.L. Wang, 2016. The effect of different carbon sources on the nutritional composition, microbial community, and structure of bioflocs. Aquaculture, 465:88-93. http://dx.doi.org/10.1016/j.aquaculture.2016.08.040

Xu W.J., Pan L.Q., Sun X.H. and J. Huang, 2013. Effects of bioflocs on water quality, and survival, growth and digestive enzyme activities of Litopenaeus vannamei (Boone) in zero-water exchange culture tanks. Aquaculture Research, 44:1093-1102. https://doi.org/10 .1111/j.1365-2109.2012.03115. 